\title{
Hygienic quality, study of enterobacteria isolated from table olives and antimicrobial activity of Olea europaea $L$ from Tetouan, Morocco
}

\author{
Zakaria MENNANE ${ }^{*}$, Jamal Abrini ${ }^{1}$ and Noureddine ELMTILI ${ }^{1}$ \\ $1^{\circ}$ Equipe alimentation et santé ; Laboratoire de biologie et santé, Faculté de Sciences Tétouan ; Université Abdelmalek Essaidi ,Morocco
}

\begin{abstract}
. 88 samples of traditional and industrial table olives were collected from various outlets in the city of Tetouan. The physical-chemical controls concerned: $\mathrm{pH}$, ORP (oxydo-reducing potential) and TDE (total dry extract). The microbiological side are: total aerobic mesophilic flora ( TAMB), total coliforms (TC), Staphylococcus aureus (SA) and lactic bacteria (LB) with an identification of the most predominant enterobacteria species and their sensitivity. Also to investigate the antimicrobial activity of Olive (Olea europaea L.) .The obtained results for traditional olives far exceed food hygiene standards, especially when $29.20 \%$ of traditional samples are too loaded in TAMB and TC and $16.5 \%$ are contaminated with SA. This shows that good hygiene practices are not respected. As for industrial olives, the averages in TAMB and SA are below the thresholds set by the standards, and only $19.8 \%$ are contaminated with TC which indicates the compliance of the majority of industrial type. Black table olives are the most contaminated. The identification results of coliforms extracted from traditional olives show the predominance of Citrobacter freundii and klebsiella pneumoniae. The sensitivity test shows that $80 \%$ of Enterobacteriaceae tested were sensitive to all antibiotics. The result showed that the ethanolic extrats was active against all bacteria.

key words: Hygienic, quality, enterobacteria, olive, antimicrobial activity
\end{abstract}

\section{Introduction}

This tree is characterized by an important medical and food properties within the fruit, leaves or other components. But, during the preparation or storage, olive can be contaminated by pathogens or chemical elements, which threaten the health of consumers, thus several studies have shown this. Like the work of Pereira.A.P (1) on traditional olives marketed in Portugal and which showed the presence of Clostridium sulphite-reducing, coliforms and fecal streptococcus, the same bacteria were detected by Z.Mennane (2)in traditional table olives from Morocco. Skandamis P.N (3) and Spyropoulou K.E et al(4) who detected Escherichia coli O157:H7 in green olives.So for staphylococcus aureus Asehraou.A (5) reported their presence in olives.

The isolation of antibiotic-resistant bacteria from food can aggravate the situation, such as the working case of Z.S El kharoussi (6) and O.O.Bello (7) who were able to isolate Enterobacteriaceae -ESBL in imported or local plant foods. Other work by S. Nabbouti (8) on these plant foods, show the predominance of Klebsiella and Escherichia, and are characterized by a penicillinase-like resistance profile in $30 \%$ of the strains tested.

All enterobacteria isolated by Nazha Haddia (9) (serratia spp, klebsiella spp and enterobacter spp), have resistance to Amoxicillin, Amoxicillin +clavulonic acid and cefalotin apart from Klebsiella spp Regarding the biological activity of olive leaves, various works have shown their antimicrobial power such as those of H.F. Al-Azzawie (10), A.N. Sudjana (11) and Lahdibi Sahraoui H(12).

To protect the health of the consumer, good hygiene practices must be respected during preparation, storage and exposure.
In our study, the hygienic quality of 88 table olive samples were assessed from 4 sites or commercial complex and identification and sensitivity of the most predominant enterobacteria species. Also another objective is to investigate the antimicrobial activity of Aqueous and ethanolic extrats ) of Olive (Olea europaea L.)

\section{Materials and Methods}

\subsection{Sampling:}

This work assesses the hygienic quality of 88 samples of black, green and pitted olives taken from markets in Tetouan region. The samples were taken periodically at nine times ( 8 traditional sales sites) and 15 industrial samples

\subsection{Physical-chemical study:}

\subsection{1 $\mathrm{pH}$ and oxydo-reducing potential(ORP):}

were determined from a broth with $20 \%$ of dry matter, using a multi-parameter $\mathrm{pH}$ after calibration, and using the AOAC method no.981.12 (AOAC,( 13)

* Corresponding author: menzakaria@hotmail.com 


\subsubsection{Total dry extract (TDE):}

In a pre-salted porcelain crucible, $10 \mathrm{~g}$ of olive is added and regulated oven for 24 hours until a constant weight is obtained.

\subsection{Microbiological study:}

\subsubsection{Total Aerobic Mesophilic Flora (TMAF):}

The TMAF count was conducted on PCA medium (Plate Count Agar) with incubation at $30^{\circ} \mathrm{C}$ for 72 hours [14].

\subsubsection{Total Coliforms (CT):}

The count was conducted on MacConkey Agar medium and the incubation at $30^{\circ} \mathrm{C} / 24 \mathrm{~h}$, the Red Colonies were counted [15].

\subsubsection{Staphylococcus aureus (SA):}

The count was conducted on Middle Baird Parker and the incubation at $37 \mathrm{oC} / 24 \mathrm{~h}[16]$

\subsubsection{Lactic bacteria:}

Extraction of lactic acid bacteria in MRS medium (Rogosa and Sharpe). The incubation occurred at $30^{\circ} \mathrm{C}$ for mesophilic species for 48 hours. After incubation, round or lenticular colonies were counted. (17)

\subsubsection{Identification of coliforms}

The identification of extraction was carried out by the search for the biochemical reaction profile using API 20E commercial kit (Bio Mérieux, Marcy l'Etoile, France).

\subsubsection{Antibiotic Susceptibility Profile}

sensitivity to antibiotics (of the 15 strains) was carried out by the method of diffusion in agar medium MuellerHinton according to the recommendations of EUCAST, The antibiotic discs (Oxoid Ltd., England) tested are:

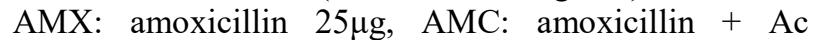

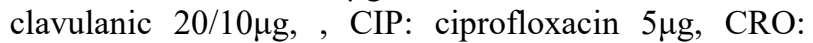
Ceftriaxone $30 \mu \mathrm{g}$, TIC: Ticarcillin $75 \mu \mathrm{g}$, NA: nalidixic

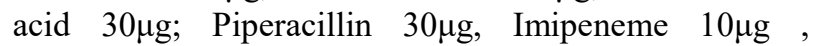
ceftazidime $30 \mu \mathrm{g}, \quad$ Piperacilline/tazobactam $30 \mu \mathrm{g}$, Nitrofuranes $100 \mu \mathrm{g}$,

The identification of extraction was carried out by the search for the biochemical reaction profile using API
20E commercial kit (Bio Mérieux, Marcy l'Etoile, France).

\subsection{Antimicrobial activity of some extracts of Olive (Olea europaea L.)}

\subsubsection{Plants collection}

Olive leaves were collected in December 2020 from Region Tanger Tetouan . The leaves were washed and dried at room temperature for 2 week, after it were ground to fine powder and stored in a good conditions until extraction.

\subsubsection{Preparation of the olive leaves extract 1}

\subsubsection{Aqueous extract}

$100 \mathrm{~g}$ of powder from the leaves were extracted by Soxhlet method for one day in $600 \mathrm{ml}$ of distilled water. Then the decoction is filtered and dehydrated [18].

\subsubsection{Organic extracts}

Extraction by the Soxhlet method of $100 \mathrm{~g}$ of leaves, for one day in $600 \mathrm{ml}$ of ethanol and subsequently evaporated by a rotary evaporator, [19]

\subsubsection{Microorganisms used}

The test organisms used included 14 bacteria strains and 1 yeast: Ten were isolated from traditional table olive (Serratia marcescens, 2 Citrobacter freundii, Klebsiella oxytoca, Enterobacter sakazakii , 2 klebsiella pneumoniae,Klvyra spp and 2 Chrysobacterium indoligenes). Candida albicans(CA) and streptococcus faecium represent American Type Culture Collection (ATCC). Three ( staphylococcus MethicillinResistant(SMR), Acinetobacter baumannii Imipenem Resistant, and were collected from the provincial hospital in Tetouan-Morocco).

\section{Results and discussion}

\subsection{Physical-chemical study:}

For physical-chemical analyses ( table 1)of traditional samples, the black-type $\mathrm{pH}$ is close to neutrality, the (ORP) is low and the (TDE) is high which is explained by the presence of the nucleus. Regarding the green type, the $\mathrm{pH}$ is very low, the (ORP) and the (TDE) are very high (nucleus presence). Then the pitted type is characterized by a high $\mathrm{pH}$ and ORP. 
Comparing between the three traditional sites, there is no significant difference between the $\mathrm{pH}$ of the different types of the same category and, that the (ORP) and (TDE) values are reconciled.

Regarding industrial samples of black olives (mark1) and candied black olives, the results are different especially at the level of ORP that is negative for the first and that is for medium confit. Also the TDE is high for mark 1.

For the samples of the cooperative, the $\mathrm{pH}$ is low, then the ORP is the highest when comparing with the other brands, and the TDE is high (nucleus presence)

For industrial pitted olives there is no difference between the brands and their Values of $\mathrm{pH}$, POR and TDE are close.

$\mathrm{pH}$ is correlated with the amount of free fatty and organic acids produced by microorganisms (20), and the recommended maximum $\mathrm{pH}$ value should be less than 4.3 (21). However, the values obtained in our study are higher than those reported above (22).

Our traditional green samples are very acidic compared to those of Hamid MOUMENE (23) for commercial olives in the Marrakech region of Morocco, and those found by Rokni (24) for green olives fermented in the laboratory

Table 1: Physical-Chemical Composition of Traditional and Industrial Olives

For traditional black olives, our $\mathrm{pH}$ results are superior than Asehraou (5) and that our TDE values are superior to him.

\subsection{Microbiological study:}

The results of microbiological characterization( table 2and 3) show that the hygienic quality of traditional samples is insufficient, so that of industrial olives is $80 \%$ satisfactory.

The coliform contamination rate of traditional black olives ranges from $40 \%$ at the Mandari and Bab Noadar sites to $67 \%$ at the Lamhanech site and for SA it varies

between 0 at the Bab Noadar site to $37.5 \%$ at the Mandari site.

So, for the green variety coliform contamination ranges from $25 \%$ at the Mandari center to about $30 \%$ at the lamhanach and Bab Noadar sites and for SA varies between $10 \%$ at the bab noadar site to $29 \%$ at the lamhanach site
Table 1: Physical-Chemical Composition of Traditional and Industrial Olives

\begin{tabular}{|c|c|c|c|c|c|}
\hline $\begin{array}{l}\text { Type } \\
\text { of } \\
\text { olive }\end{array}$ & & $\begin{array}{l}\text { Nbre OF } \\
\text { samples }\end{array}$ & $\mathrm{Ph}$ & $\begin{array}{l}\text { ORP } \\
(\mathrm{mv})\end{array}$ & $\begin{array}{l}\text { TDE } \\
(\%)\end{array}$ \\
\hline \multirow[t]{3}{*}{$\begin{array}{l}\text { Mand } \\
\text { ari }\end{array}$} & $\begin{array}{l}\text { Traditional } \\
\text { Black olives }\end{array}$ & 4 & 6.26 & 17.9 & 60.6 \\
\hline & $\begin{array}{l}\text { Traditional } \\
\text { Green }\end{array}$ & 2 & 3.3 & 193.2 & 52.5 \\
\hline & $\begin{array}{l}\text { Traditional } \\
\text { Pitted }\end{array}$ & 3 & 4.8 & 101 & 41 \\
\hline \multirow{3}{*}{$\begin{array}{l}\text { Bab } \\
\text { Noua } \\
\text { dar }\end{array}$} & $\begin{array}{l}\text { Traditional } \\
\text { Black olives }\end{array}$ & 2 & 7.13 & -68 & 65.9 \\
\hline & $\begin{array}{l}\text { Traditional } \\
\text { Green }\end{array}$ & 3 & 3.23 & 194.3 & 46.6 \\
\hline & $\begin{array}{l}\text { Traditional } \\
\text { pitted }\end{array}$ & 3 & 4.72 & 107 & 34.2 \\
\hline \multirow[t]{3}{*}{$\begin{array}{l}\text { Lamh } \\
\text { anach }\end{array}$} & $\begin{array}{l}\text { Traditional } \\
\text { Black olives }\end{array}$ & 6 & 6.26 & 17.9 & 60.6 \\
\hline & $\begin{array}{l}\text { Traditional } \\
\text { Green }\end{array}$ & 6 & 3.3 & 193.2 & 52.5 \\
\hline & $\begin{array}{l}\text { Traditional } \\
\text { pitted }\end{array}$ & 9 & 4.8 & 101 & 41 \\
\hline \multirow{2}{*}{$\begin{array}{l}\text { Indust } \\
\text { rial } \\
\text { Black }\end{array}$} & $\begin{array}{c}\text { Brand } \\
1\end{array}$ & 3 & 6 & 31.7 & $\begin{array}{l}69.3 \\
5\end{array}$ \\
\hline & $\begin{array}{l}\text { Brand } \\
2 \text { ((confits) }\end{array}$ & 3 & 3.65 & 172 & $\begin{array}{l}52.2 \\
5\end{array}$ \\
\hline $\begin{array}{l}\text { Indust } \\
\text { rial } \\
\text { Green }\end{array}$ & $\begin{array}{l}\text { Brand } \\
3 \\
\text { cooperative }\end{array}$ & 3 & 6.56 & -4.3 & 38.8 \\
\hline \multirow{2}{*}{$\begin{array}{l}\text { Indust } \\
\text { rial } \\
\text { pitted }\end{array}$} & $\begin{array}{c}\text { Brand } \\
1 \\
\end{array}$ & 3 & 3.62 & 171.1 & 24.1 \\
\hline & $\begin{array}{l}\text { Brand } \\
2\end{array}$ & 3 & 4.34 & 155 & 24.4 \\
\hline
\end{tabular}

For pitted olives samples from the Mandari and Bab Noadar sites were loaded with coliforms with a rate of 29 and $25 \%$ successively, so 15 and $12.5 \%$ of these foodstuffs were contaminated with SA in the same order. So those at the Lamhanach site were free of contamination.

Other studies have shown the contamination of olives by coliforms such as those of Pereira.A.P (1) .For Portuguese olives, Spyropoulou K.E et al(4) for green olives, Skandamis P.N (3) ,Moumene (23) in the Marrakesh and A region. MAOUNI (25) for olives from the three Moroccan cities (Fez, Marrakech and Tetouan). For staphylococcus aureus asehraou detected these germs in $55 \%$ of the analyzed black olives.

Industrial candied black and pitted type samples are $100 \%$ compliant. Probably the sterilization of candied olives, and the use of preservatives for the pitted type are the causes. 
Then those of green type prepared by cooperatives and the black type were contaminated by total coliforms at a rate of $33 \%$ and $66 \%$ successively.

The use of sections to divide the text of the paper is optional and left as a decision for the author. Where the author wishes to divide the paper into sections the formatting shown in Table 2 should be used.

Table 2: Microbiological Composition of Industrial Olives

\begin{tabular}{|c|c|c|c|c|c|c|c|c|c|}
\hline \multirow{2}{*}{$\begin{array}{l}\text { Typ } \\
\mathrm{e} \\
\text { of } \\
\text { oliv } \\
\mathrm{e}\end{array}$} & \multirow[t]{2}{*}{ (PS) } & \multirow[t]{2}{*}{$\begin{array}{l}\mathrm{N} \\
\mathrm{b}\end{array}$} & \multicolumn{2}{|c|}{$\begin{array}{l}\text { SPS } \\
10^{4} \\
\mathrm{ufc} / \mathrm{ml}\end{array}$} & \multicolumn{2}{|c|}{$\begin{array}{l}\mathrm{TC} \\
10^{3} \\
\mathrm{ufc} / \mathrm{ml}\end{array}$} & \multicolumn{2}{|c|}{$\begin{array}{l}\text { SA } \\
10 \\
{ }^{3} \mathrm{ufc} / \mathrm{m} \\
1\end{array}$} & \multirow[t]{2}{*}{$\begin{array}{l}\text { LB } \\
10^{3} \\
\text { ufc/ } \\
\mathrm{ml}\end{array}$} \\
\hline & & & av & $\begin{array}{l}\% \mathrm{~N} \\
\mathrm{C}\end{array}$ & $\begin{array}{l}\mathrm{A} \\
\mathrm{V}\end{array}$ & $\begin{array}{l}\% \\
\mathrm{~N} \\
\mathrm{C}\end{array}$ & $\begin{array}{l}\mathrm{A} \\
\mathrm{v}\end{array}$ & $\begin{array}{l}\% \\
\mathrm{~N} \\
\mathrm{C}\end{array}$ & \\
\hline \multirow{2}{*}{$\begin{array}{l}\text { Ind } \\
\text { ustr } \\
\text { ial } \\
\text { Bla } \\
\text { ck }\end{array}$} & $\begin{array}{l}\text { Bran } \\
\text { d } 1\end{array}$ & 3 & $\begin{array}{l}0 . \\
33\end{array}$ & 0 & 3 & 66 & 0 & 0 & 0 \\
\hline & $\begin{array}{l}\text { Bran } \\
\mathrm{d} \quad 2 \\
\text { (con } \\
\text { fits) }\end{array}$ & 3 & 0 & 0 & 0 & 00 & 0 & 0 & 0 \\
\hline $\begin{array}{l}\text { Ind } \\
\text { ustr } \\
\text { ial } \\
\text { Gre } \\
\text { en }\end{array}$ & $\begin{array}{l}\text { Bran } \\
\text { d } 3 \\
\text { Coo } \\
\text { pera } \\
\text { tive }\end{array}$ & 3 & $\begin{array}{l}4 . \\
3\end{array}$ & 0 & $\begin{array}{l}19 \\
.7\end{array}$ & 33 & 0 & 0 & 0 \\
\hline $\begin{array}{l}\text { Ind } \\
\text { ustr } \\
\text { ial }\end{array}$ & $\begin{array}{l}\text { Bran } \\
\text { d } 1 \\
\text { et } 2\end{array}$ & 6 & 0 & 0 & 00 & 0 & 0 & 0 & 0 \\
\hline
\end{tabular}

\subsection{Identification of coliforms and Antibiotic Susceptibility Profile}

15 strains of enterobacteria were extracted. Biochemical identification of the former showed the predominance of Citrobacter freundii , klebsiella pneumoniae and Chrysobacterium indoligenes, followed by Klebsiella oxytoca , Enterobacter sakazaki, Klvyra spp, and Serratia marcescens.

the sensitivity test shows that $80 \%$ of Enterobacteriaceae (Serratia marcescens, Citrobacter freundii, klebsiella pneumoniae, Chrysobacterium indoligenes and Chrysobacterium spp) tested were sensitive to all antibiotics.
Table 3: Microbiological Composition of Olives

\begin{tabular}{|c|c|c|c|c|c|c|c|c|c|}
\hline \multirow{2}{*}{$\begin{array}{l}\text { Typ } \\
\text { e of } \\
\text { oliv } \\
\text { e }\end{array}$} & & \multirow{2}{*}{$\begin{array}{l}\text { Nbre } \\
\text { of } \\
\text { samp } \\
\text { le }\end{array}$} & \multicolumn{2}{|c|}{$\begin{array}{l}\text { SPS } \\
10^{4} \\
\mathrm{ufc} / \mathrm{ml} \\
\end{array}$} & \multicolumn{2}{|c|}{$\begin{array}{l}\text { TC } \\
10^{3} \\
\mathrm{ufc} / \mathrm{ml}\end{array}$} & \multicolumn{2}{|c|}{$\begin{array}{l}\text { SA } \\
10^{3} \\
u f c / m l\end{array}$} & \multirow{2}{*}{$\begin{array}{l}\text { lactic } \\
\text { Bact } \\
10^{3} \\
\text { ufc/ } \\
\mathrm{ml}\end{array}$} \\
\hline & & & $\begin{array}{l}\text { av } \\
\text { era } \\
\text { ge }\end{array}$ & $\begin{array}{l}\% \\
\mathrm{~N} \\
\mathrm{~N} \\
\mathrm{C}\end{array}$ & $\begin{array}{l}\text { av } \\
\text { era } \\
\text { ge }\end{array}$ & $\begin{array}{l}\% \\
\mathrm{~N} \\
\mathrm{C}\end{array}$ & $\begin{array}{l}\text { av } \\
\text { era } \\
\text { ge }\end{array}$ & $\begin{array}{l}\% \\
\mathrm{~N} \\
\mathrm{C}\end{array}$ & \\
\hline \multirow[t]{3}{*}{$\begin{array}{l}\text { Man } \\
\text { dari }\end{array}$} & $\begin{array}{l}\text { Traditi } \\
\text { onal } \\
\text { Black } \\
\text { olives }\end{array}$ & 8 & 8.1 & 0 & 3.2 & 40 & $\begin{array}{l}1.2 \\
5\end{array}$ & $\begin{array}{l}37 . \\
5\end{array}$ & 7 \\
\hline & $\begin{array}{l}\text { Traditi } \\
\text { onal } \\
\text { Green }\end{array}$ & 8 & 6 & 0 & 2.4 & 25 & $\begin{array}{l}0.2 \\
5\end{array}$ & $\begin{array}{l}12 . \\
5\end{array}$ & 7 \\
\hline & $\begin{array}{l}\text { Traditi } \\
\text { onal } \\
\text { pitted }\end{array}$ & 7 & 4 & 0 & 1.6 & 29 & 0.5 & 15 & 0.3 \\
\hline \multirow[t]{3}{*}{$\begin{array}{l}\text { Bab } \\
\text { Nou } \\
\text { adar }\end{array}$} & $\begin{array}{l}\text { Traditi } \\
\text { onal } \\
\text { Black } \\
\text { olives }\end{array}$ & 10 & 12 & 0 & 17 & 40 & 0 & 0 & 42 \\
\hline & $\begin{array}{l}\text { Traditi } \\
\text { onal } \\
\text { Green }\end{array}$ & 10 & 27 & 20 & $\begin{array}{l}27 \\
0\end{array}$ & 30 & 0.4 & 10 & 10.5 \\
\hline & $\begin{array}{l}\text { Traditi } \\
\text { onal } \\
\text { pitted }\end{array}$ & 8 & 16 & $\begin{array}{l}12 . \\
5\end{array}$ & 1.5 & 25 & 0.1 & $\begin{array}{l}12 . \\
5\end{array}$ & 5 \\
\hline \multirow[t]{3}{*}{$\begin{array}{l}\text { Lam } \\
\text { hana } \\
\text { ch }\end{array}$} & $\begin{array}{l}\text { Traditi } \\
\text { onal } \\
\text { Black } \\
\text { olives }\end{array}$ & 9 & $\begin{array}{l}32 \\
5\end{array}$ & 11 & $\begin{array}{l}12 \\
8\end{array}$ & 67 & 3.3 & 33 & 50 \\
\hline & $\begin{array}{l}\text { Traditi } \\
\text { onal } \\
\text { Green }\end{array}$ & 6 & $\begin{array}{l}27 \\
5\end{array}$ & 14 & $\begin{array}{l}73 . \\
2\end{array}$ & 29 & 9.3 & 29 & 6.3 \\
\hline & $\begin{array}{l}\text { Traditi } \\
\text { onal } \\
\text { pitted }\end{array}$ & 7 & 5.6 & 0 & 0 & 0 & 0 & 0 & 2.3 \\
\hline \multirow{2}{*}{$\begin{array}{l}\text { Indu } \\
\text { stria } \\
1 \\
\text { Blac } \\
\mathrm{k}\end{array}$} & $\begin{array}{l}\text { Brand } \\
1\end{array}$ & 3 & $\begin{array}{l}0.3 \\
3\end{array}$ & 0 & 3 & 66 & 0 & 0 & 0 \\
\hline & $\begin{array}{l}\text { Brand } \\
2 \\
\text { (confits } \\
\text { ) }\end{array}$ & 3 & 0 & 0 & 0 & 00 & 0 & & 0 \\
\hline $\begin{array}{l}\text { Indu } \\
\text { stria } \\
1 \\
\text { Gree } \\
n\end{array}$ & $\begin{array}{l}\text { Brand } \\
3 \\
\text { cooper } \\
\text { ative }\end{array}$ & 3 & 4.3 & 0 & $\begin{array}{l}19 . \\
7\end{array}$ & 33 & 0 & & 0 \\
\hline $\begin{array}{l}\text { Indu } \\
\text { stria } \\
1 \\
\text { pitte } \\
d\end{array}$ & $\begin{array}{l}\text { Brand } \\
1 \text { et } 2\end{array}$ & 6 & 0 & 0 & 00 & 0 & 0 & & 0 \\
\hline
\end{tabular}


Table 4:Identification of coliforms and Antibiotic Susceptibility Profile

\begin{tabular}{|c|c|c|c|c|c|c|}
\hline $\begin{array}{l}\text { Species of } \\
\text { Entero } \\
\text { bacteriaceae }\end{array}$ & Number & $\begin{array}{l}\text { Rate } \\
\%\end{array}$ & $\begin{array}{l}\text { F } \\
\text { TOB } \\
\text { IMP } \\
\text { CIP } \\
\text { TZP } \\
\text { PIP } \\
\text { CAZ } \\
\text { AMC }\end{array}$ & CRO & AML & TIC \\
\hline $\begin{array}{l}\text { Serratia } \\
\text { marcescens }\end{array}$ & 1 & 6.7 & $\mathrm{~S}$ & $\mathrm{~S}$ & $\mathrm{~S}$ & $\mathrm{~S}$ \\
\hline \multirow[b]{3}{*}{$\begin{array}{l}\text { Citrobacter } \\
\text { freundii }\end{array}$} & \multirow[b]{3}{*}{3} & \multirow[b]{3}{*}{20} & $\mathrm{~S}$ & $\mathrm{~S}$ & $\mathrm{~S}$ & $\mathrm{~S}$ \\
\hline & & & $\mathrm{S}$ & S & S & S \\
\hline & & & $\mathrm{S}$ & S & S & S \\
\hline \multirow[b]{4}{*}{$\begin{array}{l}\text { Chrysobacterium } \\
\text { spp }\end{array}$} & \multirow[b]{4}{*}{4} & \multirow[b]{4}{*}{26.7} & $\mathrm{~S}$ & $\mathrm{R}$ & $\mathrm{S}$ & $\mathrm{S}$ \\
\hline & & & $\mathrm{S}$ & S & S & S \\
\hline & & & $\mathrm{S}$ & S & S & S \\
\hline & & & $\mathrm{S}$ & $\mathrm{S}$ & S & $\mathrm{S}$ \\
\hline $\begin{array}{l}\text { Klebsiella } \\
\text { oxytoca }\end{array}$ & 1 & 6.7 & $\mathrm{~S}$ & $\mathrm{~S}$ & $\mathrm{R}$ & $\mathrm{R}$ \\
\hline $\begin{array}{l}\text { Enterobacter } \\
\text { sakazaki }\end{array}$ & 1 & 6.7 & $\mathrm{~S}$ & $\mathrm{~S}$ & $\mathrm{R}$ & $\mathrm{R}$ \\
\hline \multirow[b]{3}{*}{$\begin{array}{l}\text { klebsiella } \\
\text { pneumoniae }\end{array}$} & \multirow[b]{3}{*}{3} & \multirow[b]{3}{*}{20} & $\mathrm{~S}$ & $\mathrm{~S}$ & $\mathrm{~S}$ & $\mathrm{~S}$ \\
\hline & & & $\mathrm{S}$ & $\mathrm{S}$ & $\mathrm{S}$ & $\mathrm{S}$ \\
\hline & & & $\mathrm{S}$ & $\mathrm{S}$ & S & S \\
\hline Klvyra spp & 1 & 6.7 & $\mathrm{~S}$ & S & $\mathrm{R}$ & $\mathrm{R}$ \\
\hline $\begin{array}{l}\text { Chrysobacterium } \\
\text { indoligenes }\end{array}$ & 1 & 6.7 & $\mathrm{~S}$ & S & S & $\mathrm{S}$ \\
\hline Total & 15 & 100 & $\mathrm{~S}$ & $\mathrm{~S}$ & S & S \\
\hline
\end{tabular}

Then 3 strains (20\%) (Klvyra spp, Enterobacter sakazaki and Klebsiella oxytoca are resistant to ticarcillin and amoxicillin and only one Chrysobacterium spp strain is resistant to ceftriaxone. (Table 4 )

Other works have also mentioned the contamination of olives by these germs such as the study of faid (26) on the deterioration of Moroccan olives before fermentation by Serratia marcescens, hafia alvei and Enterobacter . Also, Sri Harminda Pahmhartantyo (27) in Singapore found by the molecular dignostic the klebsiella pneumoniae in plant foods and which were sometimes mult-resistant with a rate of $21 \%$ of isolated strains.

Other research by Ghita Benjelloun Touimi (28) that could be extracted from Serratia marcescens, Serratia odorifera from plant-based foods prepared in Moroccan hospital facilities.

Pathogens isolated by Poorna Viswanathan (29) from raw vegetables and fruits were E. coli, Enterobacter sp., Klebsiella sp., S. typhi, Serratia sp.,
Providencia sp. and P. aeruginosa. Antibiotic resistance of the isolates revealed $\mathrm{P}$. aeruginosa to be the most antibiotic resistant.

Monica Österblad (30) showed that in vegetable samples, the Enterobacter spp were most frequent, Escherichia coli was rare. No resistance was found to cefotaxime, aztreonam, imipenem, gentamicin, nalidixic acid or ciprofloxacin

Rabia Razzaq (31) found E. coli, Enterobacter spp. and Salmonella spp in fresh vegetables. Also all the strains were sensitive to ampicillin, erythromycin, kanamycin and nalidixic acid.

\subsection{Antimicrobial activity of some extracts of Olive (Olea europaea L.)}

Ethanolic extracts from olive leaves have shown inhibitory activity towards all bacteria. Especially on Chrysobacterium indoligenes and Chrysobacterium spp with an inhibition diameter of $40 \mathrm{~mm}$ followed by methicillin-resistant staphylococcus and in third position comes klebsiella pneumoniae, Serratia marcescens and CA with a diameter of $24 \mathrm{~mm}$; thereafter comes

Citrobacter freundii and Klvyra spp.

But the aqueous extract is only effective on Klvyra spp with a diameter of $15 \mathrm{~mm}$. (Table 5)

These results encourage the use of these ethanolic extracts of olive leaves for the preservation of table olives.

Also Sahraoui (12) found that methanolic extracts of the leaves are active on enterobacteria like K.pneumoniaa, Citrobacter freundii, enterobacter spp and staphylococcus. But some aqueous extracts of sahrawi are active on all bacteria tested

Other works have also shown their antimicrobial power such as those of H.F. Al-Azzawie (10) and A.N. Sudjana (11)

Table 5 Antimicrobial activity of some extracts of Olive (Olea europaea L.)

\begin{tabular}{|l|l|l|}
\hline Species & $\begin{array}{l}\text { Diameter } \\
(\mathrm{mm}) \\
\text { Ethanolic } \\
\text { extracts }\end{array}$ & $\begin{array}{l}\text { Diameter } \\
(\mathrm{mm}) \\
\text { aqueous } \\
\text { extract }\end{array}$ \\
\hline $\begin{array}{l}\text { Serratia marcescens } \\
\text { klebsiella } \\
\text { pneumoniae }\end{array}$ & 0 \\
\hline $\begin{array}{l}\text { Citrobacter freundii } \\
\text { Enterobacter }\end{array}$ & 16 & 0 \\
\hline sakazaki & 20 & 0 \\
\hline Klvyra spp & 10 & 0 \\
\hline $\begin{array}{l}\text { Chrysobacterium } \\
\text { indoligenes }\end{array}$ & 40 & 15 \\
\hline $\begin{array}{l}\text { Chrysobacterium } \\
\text { spp }\end{array}$ & 40 & 0 \\
\hline $\begin{array}{l}\text { staphylococcus } \\
\text { Methicillin-Resistant }\end{array}$ & 25 & 0 \\
\hline CA & 24 & 0 \\
\hline
\end{tabular}




\section{Conclusion:}

Microbiological tests show the contamination of about $30 \%$ of traditional samples by fecal flora and that is a good indicator of deplorable hygiene conditions. In terms of pathogenic bacteria, we mention staphylococcus aureus with a rate of $16 \%$ which poses a threat to the consumer. the results of identification of enterobacteria isolated from olives show the predominance of Citrobacter freundii and klebsiella pneumoniae.

This requires informing the preparers of this situation, to raise their awareness and train them to respect the conditions of hygiene (thermal treatment, cleaning in accordance with the standards and the proper packaging and storage of their finished products). The sensitivity test shows that the majority were sensitive to all antibiotics and that ethanolic extracts were active against all bacteria

\section{References}

1- A. P. Pereira, J.A. Pereira, A. M. Bento, L. Estevin, Food Chem Toxicol 46: 2895-2902 (2008)

2- Z Mennane, I. Houlali, R. Charof, J.Abrini, N.Elmtili, African J. Clin. Exp. Microbiol 22.1(2021)

3- P. N. Skandamis, G.-J. E. Nychas. J. Food Prot 66, 7(2003),

4- K.E. Spyropoulou, N.G Chorianopoulos, P.N Skandamis, G.-J.E Nychas , Int. J. Food Microbiol 66, 1-2(2001)

5- A.Asehraou, M.Faid, and M. Jana .Grasas Aceites 43, 3(1992)

6- Z. S. Al-Kharousi, N. Guizani, A. M. Al-Sadi, I. M. Al-Bulushi, J. Food Prot 82, 11(2019)

7- O.O .Bello, MO .Oni, JO .Bello, TK .Bello, J FOOD SCI 9(1) (2019)

8- S. Nabbouti, A. Hasib, K. Khedid, A. Quasmaoui,G. Al Askari ,Z. Mennane, J. Mater. Environ. Sci 5 (3) (2014)

9- N. Haddia, Z. MENNANE, R. Charof, E. BERNY, A. MARDHY, E. KERAK. IJIAS 12, 3 ( 2015)

10- H.F. Al-Azzawie, M.S.S. Alhamdani, Life Sci 78,12 (2006)

11- A.N. Sudjana. C.D. Orazio, V. Ryan, N. Rasool, J. $\mathrm{Ng}$, N. Islam, T.V. Riley, K.A. Hammer, I. J, Antimicrob. Agents. 33,5 (2009)

12- H .L. Sahraoui, H .El Berny, M .El Karkour, A.Quasmaoui, R .Charof, Z .Mennane, Der Pharma Chem 9(13)(2017)

13- A. O. A. C. Official methods of analysis. Association of Official Analytical Chemists( 15th Edition, Washington, D.C., USA 1990. methods 920.149 (c), 942.15A ,942.15 and 981.12)

14- NM ISO 4833, 2008. Food Microbiology Horizontal Method for Counting Microorganisms Colony Counting Technique at $300 \mathrm{C}$. (Rev, IC08.4.102, 13).
15- Standards NM 08.0.124. Food Microbiology Counting thermotolerant Coliforms by colony counting at $44 \mathrm{oC}$ (Routine method, 2006; $\mathrm{p} 8$ )

16- NM ISO 6888-1., 2008. Food Microbiology Horizontal method for counting positive coagulasis staph (Rev, IC08.0.150, 21)

17- NF ISO 15214 (V 08-030). September 1998. Food microbiology. Horizontal method for counting mesophilic lactic bacteria. Colony counting technique at $30^{\circ} \mathrm{C}$..

18- J.B. Harbone, Photochemical methods a guide to modern techniques of plant analysis (Halsted press, ,New York, 1976)

19- A.M. Dub, A.M. Dugani, Libyan J. Med 8, 1 (2013).

20. F.Sakouhi, S.Harrabi, C.Absalon,, K.Sbei,, S.Boukhchin and H. Kallel, Food Chem 108, 3 (2008).

21. IOC; International Olive Council, 2007

22. P. Efstathios and Z. K. Constantinos, Food Microbiol 23, 2 (2006)

23- H.Moumene, A.Hasib, S.Amir, A. Jaouad, Les technologies de laboratoire 8, 32 (2013).

24-Y. Rokni, N. Ghabbour, N.Chihib, .Thonart,A.Asehraou, J. Mater. Environ. Sci 6, 6 (2015)

25- A.Maouni, M.Khaddor, A.,Lamarti,and A. Badoc, Bull Soc Pharm Bordeaux. 141,1 (2002).

26-M.FAID, R.Achartouf and A.Asehraou.,Grasa Aceites 45, 5 (1994).

27-S. Pahm hartantyo, M.chau, T. Hsien koh, M. Yap, T. YI, D. Yan hong cao, R.A. gutiérrez, L. Ching ng,J. Food Prot 83 7(2020)

28-G.B. Touimi, L.Bennani, S.Berrada, M.Benboubker , B.Bennani, Iran. J. Microbiol 11, 6 (2019)

29-P. Viswanathan, R. Kaur, Int J Hyg Envir Heal . 203, 3 (2001)

30-M.Österblad, O. Pensala, M. Peterzéns, H.Heleniusc, P. Huovinen, J. Antimicrob. Chemother 43, 4 ( 1999)

31-R. Razzaq, K. Farzana, S.Mahmoodand ,G.Murtaza , Pakistan J. Zool 46,4( 2014) 